\title{
First-in-Man Study of Simvastatin-Eluting Stent in De Novo Coronary Lesions - The SIMVASTENT Study -
}

\author{
Alexandre C. Zago, MD, PhD; Bruno S. Matte, MD; Luciana Reginato; \\ Germán Iturry-Yamamoto, MD, PhD; Ana Krepsky, MD; \\ Luiz Carlos C. Bergoli, MD; Julise Balvedi; José C. Raudales, MD, PhD; \\ Eduardo K. Saadi, MD, PhD; Alcides J. Zago, MD, PhD
}

\begin{abstract}
Background: Statins have anti-inflammatory and antiproliferative properties irrespective of their cholesterol-lowering effects. The aim of the present study was to evaluate a simvastatin-eluting stent (SimvES) in the treatment of de novo coronary lesions.
\end{abstract}

\begin{abstract}
Methods and Results: Forty-two patients with de novo coronary artery lesions were assigned to SimvES, baremetal stent (BMS) or everolimus-eluting stent (EES) implantation followed by intravascular ultrasound (IVUS) for neointimal quantitative analysis. Six months later, quantitative coronary angiography (QCA) and IVUS were repeated. QCA showed no binary restenosis, a mean in-stent late loss of $1.05 \pm 0.25 \mathrm{~mm}$ (BMS, $1.12 \pm 0.48 \mathrm{~mm}$; EES, $0.20 \pm 0.16 \mathrm{~mm}$ ) and a diameter stenosis of $33.5 \pm 7.1 \%$ (BMS, $35.5 \pm 15.30 \%$; EES, $7.2 \pm 3.12 \%$ ). Control IVUS showed a mean in-stent obstruction of $18.3 \pm 9.4 \%$ (BMS, 32.8 $\pm 19.1 \%$; EES, $9.8 \pm 2.4 \%$ ) and a neointimal volume index of $1.58 \pm 0.75 \mathrm{~mm}^{3} / \mathrm{mm}$ (BMS, $2.93 \pm 1.76 \mathrm{~mm}^{3} / \mathrm{mm}$; EES, $0.80 \pm 0.16 \mathrm{~mm}^{3} / \mathrm{mm}$ ). Thrombus, late incomplete apposition and major adverse cardiac events were not observed.
\end{abstract}

Conclusions: In this sample of patients with de novo coronary lesions, the use of a SimvES was not related to major adverse cardiac events, but it was associated with a higher level of neointimal proliferation than expected. (Circ $J$ 2012; 76: 1109-1114)

Key Words: Drug-eluting stent; Intravascular ultrasound; Simvastatin; Statins; Stent

$\mathbf{S}$ atins have anti-inflammatory and antiproliferative properties irrespective of their cholesterol-lowering effects. They reduce leukocyte adhesion, platelet aggregation, monocyte activation, and C-reactive protein levels, ${ }^{1}$ which are components of the inflammatory process that drives all phases of atherosclerosis. ${ }^{2}$ Experimental studies have shown that statins reduce both inflammatory response and neointimal hyperplasia after angioplasty and stent implantation..$^{3-7}$ Moreover, meta-analyses of human trials and porcine models have shown that oral statins reduce restenosis after stent deployment. ${ }^{8,9} \mathrm{~A}$ pre-clinical study in swine with the simvastatin-eluting stent (SimvES) under evaluation in the present trial showed that it significantly reduced neointimal thickening compared to baremetal stents (BMS). ${ }^{10}$

In light of its anti-inflammatory and antiproliferative properties, simvastatin seems to be a promising agent for prevention of in-stent restenosis. It may also have a more physiological mechanism of action than the antiproliferative drugs used in current drug-eluting stents (DES), because its anti-restenosis properties do not significantly interfere with re-endothelialization. ${ }^{11}$

This first-in-man, prospective, controlled study evaluated a SimvES in the treatment of de novo coronary lesions using intravascular ultrasound (IVUS).

\section{Subjects}

Forty-two patients with single de novo lesions $\leq 14 \mathrm{~mm}$ in length in coronary arteries of $3.0-3.8 \mathrm{~mm}$ in diameter were assigned to receive a SimvES (14 patients), BMS (14 patients), or an everolimus-eluting stent (EES; 14 patients). The BMS and EES groups were used as controls. Patients with left main coronary artery, ostial and/or bifurcation lesions were not included in order to avoid interference of technique issues in the results. ${ }^{12-14}$ Atrial fibrillation was an exclusion criterion because, according

Received October 4, 2011; revised manuscript received December 22, 2011; accepted January 12, 2012; released online February 21,

2012 Time for primary review: 31 days

Cardiovascular Research Center, Lutheran University of Brazil, Canoas, RS, Brasil

Mailing address: Alexandre do Canto Zago, MD, PhD, Cardiovascular Research Center, Universidade Luterana do Brasil/ULBRA, Av.

Farroupilha, 8001, prédio 22, 5o andar, Canoas, RS, Brasil CEP 92425-900. E-mail: zagoac@uol.com.br

ISSN-1346-9843 doi:10.1253/circj.CJ-11-1125

All rights are reserved to the Japanese Circulation Society. For permissions, please e-mail: cj@j-circ.or.jp 


\begin{tabular}{lcccc}
\hline Table 1. Baseline Clinical and Procedural Characteristics & & & \\
$\quad$ Characteristics & BMS & SimvES & EES & P value \\
Age (years) & $59.8 \pm 8.7$ & $62.6 \pm 9.9$ & $63.9 \pm 7.8$ & 0.46 \\
Male gender & $10(71.4)$ & $11(78.5)$ & $10(71.4)$ & 1.0 \\
Diabetes mellitus & $4(28.6)$ & $5(35.7)$ & $5(35.7)$ & 1.0 \\
Hypertension & $10(71.4)$ & $11(78.6)$ & $12(85.7)$ & 0.89 \\
Smoking & $11(78.6)$ & $10(71.4)$ & $10(71.4)$ & 1.0 \\
Dyslipidemia & $11(78.6)$ & $9(64.3)$ & $10(71.4)$ & 0.91 \\
Clinical presentation & & & & 1.0 \\
ACS (non-ST elevation) & $9(64.3)$ & $8(57.2)$ & $8(57.1)$ & \\
Stable angina & $5(35.7)$ & $6(42.8)$ & $6(42.9)$ & 1.0 \\
Target vessel & & & & \\
LAD & $6(42.9)$ & $5(35.7)$ & $6(42.9)$ & $1(7.1)$ \\
LCX & $2(14.3)$ & $2(14.3)$ & $7(50)$ & 1.0 \\
RCA & $6(42.9)$ & $7(50)$ & $14(100)$ & \\
ASA & $14(100)$ & $14(100)$ & & \\
Thienopyridine & $13(92.9)$ & $13(92.9)$ & $14(100)$ & 0 \\
Clopidogrel & $1(7.1)$ & $1(7.1)$ & & \\
Ticlopidine & & &
\end{tabular}

Data given as mean $\pm \mathrm{SD}$ and $\mathrm{n}(\%)$.

BMS, bare-metal stent; SimvES, simvastatin-eluting stent; EES, everolimus-eluting stent; ACS, acute coronary syndrome; LAD, left descending anterior coronary artery; LCX, left circumflex coronary artery; RCA, right coronary artery; ASA, acetylsalicylic acid.

to current guidelines, patients with a compelling indication for long-term anticoagulation should undergo BMS implantation or coronary artery bypass graft (CABG) over DES to restrict the duration of triple therapy to 1 month. ${ }^{15}$ Also, patients with ST elevation acute coronary syndrome, visible thrombus on angiography, and excessive calcified culprit lesion, as well as patients who underwent thrombus aspiration or received glycoprotein IIb/IIIa inhibitors, were not included in order to avoid bias in the results arising from anatomical, technical, or pharmacological issues not related to the stent. The Ethics Committee of the institution where the study was conducted approved the protocol, and patients provided written informed consent prior to the procedure.

\section{SimvES}

The stents implanted were 316L stainless steel balloon-expandable stents loaded with $0.4 \mu \mathrm{g} / \mathrm{mm}^{2}$ simvastatin and coated with a biocompatible and non-absorbable polymer, delivering $30 \%$ of the total drug load in 14 days and approximately $40 \%$ in 30 days, according to the manufacturer.

\section{Procedure}

Stent deployment was guided by IVUS performed before and at the end of the procedure to ensure stent apposition and to assess the final result. Pre-dilatation of the target lesion was performed at the operator's discretion. All patients received $100 \mathrm{mg}$ aspirin daily indefinitely, started at least $24 \mathrm{~h}$ before the procedure at a loading dose of $300 \mathrm{mg}$, or 5 days before the procedure with no loading dose. They were also treated with $75 \mathrm{mg}$ clopidogrel daily for 6 months, started $\geq 2 \mathrm{~h}$ before the procedure at a loading dose of $600 \mathrm{mg}$ (or $\geq 12 \mathrm{~h}$ before the procedure at a loading dose of $300 \mathrm{mg}$, or $>48 \mathrm{~h}$ before the procedure with no loading dose). Six months later, coronary angiography, IVUS and clinical follow-up were performed.

\section{Quantitative Measurements}

Quantitative coronary angiography (QCA) and IVUS were performed immediately after the procedure and at 6-month follow-up in all patients after a bolus infusion of i.c. nitrate.
IVUS images were acquired using motorized pull-back at a constant speed of $0.5 \mathrm{~mm} / \mathrm{s}$. Mean stent volume, mean neointimal volume and mean in-stent obstruction were measured and calculated. The percentage of in-stent obstruction was then calculated as neointimal volume/stent volume $\times 100$, and the neointimal volume index was calculated as mean neointimal volume/stent length. The percentage of in-stent obstruction and the neointimal volume index were used to compare the results in the 3 stent groups in order to balance a small difference of $1 \mathrm{~mm}$ in stent length between the SimvES (stent length $14 \mathrm{~mm}$ ) and the EES and BMS groups (stent length $15 \mathrm{~mm}$ ).

\section{Statistical Analysis}

A sample size of 10 patients per treatment group (total 30 patients) was calculated for a statistical power of $90 \%$ and an alpha error of 0.05 ; nevertheless, 14 patients per treatment group (total 42 patients) were enrolled in this study in order to minimize loss to follow-up.

Continuous variables are described as mean $\pm \mathrm{SD}$, and categorical data, as absolute and relative frequencies. Fisher's exact test was used for analysis of the categorical data, while 1-way analysis of variance (ANOVA) followed by the Tukey test for multiple comparisons was performed for comparison of continuous variables in the 3 different treatment groups. The $\mathrm{P}$-values obtained from ANOVA refer to the general comparison of the 3 treatment groups. Different letters mean statistically significant differences between the means of the groups after multiple comparisons using the Tukey test. The level of significance was set at $\mathrm{P}<0.05$.

\section{Results}

The baseline clinical and procedural characteristics of the 42 patients enrolled in this first-in-man study indicated diabetes mellitus in $33.3 \%$ and acute coronary syndrome in $59.5 \%$ of the study participants, with no significant difference between the 3 groups (Table 1). All stents were implanted successfully, and all patients were discharged $24-48 \mathrm{~h}$ after the procedure 


\begin{tabular}{|c|c|c|c|c|}
\hline Characteristics & BMS & SimvES & EES & $P$ value \\
\hline \multicolumn{5}{|l|}{ Before stenting } \\
\hline MLD (mm) & $0.63 \pm 0.36$ & $0.59 \pm 0.32$ & $0.60 \pm 0.29$ & 0.94 \\
\hline DS (\%) & $76.8 \pm 7.85$ & $80.1 \pm 8.41$ & $79.3 \pm 7.35$ & 0.52 \\
\hline \multicolumn{5}{|l|}{ After stenting } \\
\hline In-stent MLD (mm) & $3.15 \pm 0.24$ & $3.14 \pm 0.25$ & $3.12 \pm 0.27$ & 0.95 \\
\hline In-stent DS (\%) & $7.7 \pm 4.5$ & $7.8 \pm 4.8$ & $7.5 \pm 5.2$ & 0.98 \\
\hline \multicolumn{5}{|l|}{ Follow-up } \\
\hline In-stent MLD (mm) & $2.03 \pm 0.40^{a}$ & $2.08 \pm 0.23^{a}$ & $2.92 \pm 0.26^{b}$ & $<0.001$ \\
\hline In-stent DS (\%) & $35.5 \pm 15.30^{a}$ & $33.5 \pm 7.13^{a}$ & $7.2 \pm 3.12^{b}$ & $<0.001$ \\
\hline In-stent late loss (mm) & $1.12 \pm 0.48^{\mathrm{a}}$ & $1.05 \pm 0.25^{\mathrm{a}}$ & $0.20 \pm 0.16^{b}$ & $<0.001$ \\
\hline Binary restenosis* & $14.3(2 / 14)$ & 0 & 0 & 0.32 \\
\hline
\end{tabular}

Data given as mean \pm SD. *Data given as ' $\%(n)$ '.

a-cDifferent letters, statistically significant differences between the means of the groups after multiple comparisons using Tukey test.

MLD, minimal lumen diameter; DS, diameter of stenosis. Other abbreviations see in Table 1.

\begin{tabular}{|c|c|c|c|c|}
\hline Characteristics & BMS & SimvES & EES & $P$ value \\
\hline Stent volume $\left(\mathrm{mm}^{3}\right)$ & $134.3 \pm 11.9$ & $121.3 \pm 11.2$ & $129.0 \pm 11.6$ & - \\
\hline Lumen volume $\left(\mathrm{mm}^{3}\right)$ & $90.2 \pm 16.2$ & $99.1 \pm 12.1$ & $116.4 \pm 9.8$ & - \\
\hline Neointimal volume (mm³/stent) & $44.0 \pm 26.4$ & $22.2 \pm 10.5$ & $12.6 \pm 2.5$ & - \\
\hline Neointimal volume index $\left(\mathrm{mm}^{3} / \mathrm{mm}\right)$ & $2.93 \pm 1.76^{a}$ & $1.58 \pm 0.75^{b}$ & $0.80 \pm 0.16^{c}$ & $<0.001$ \\
\hline In-stent volume of obstruction (\%) & $32.8 \pm 19.1^{\mathrm{a}}$ & $18.3 \pm 9.4^{b}$ & $9.8 \pm 2.4^{c}$ & $<0.001$ \\
\hline
\end{tabular}

without any complications. No significant elevations in enzyme levels (creatine kinase [CK] and CK-MB) were observed among these patients.

Angiographic follow-up at 6 months showed neither binary restenosis nor stent thrombosis according to the ARC definition $^{16}$ in the SimvES and EES groups, but there were 2 cases of restenosis in the BMS group (14.3\%). Quantitative coronary analysis indicated an in-stent late loss of $1.05 \pm 0.25 \mathrm{~mm}$, $12 \pm 0.48 \mathrm{~mm}$ and $0.20 \pm 0.16 \mathrm{~mm}$ and an in-stent diameter stenosis of $33.5 \pm 7.13 \%, 35.5 \pm 15.30 \%$ and $7.2 \pm 3.12 \%$ in the SimvES, BMS, and EES groups, respectively (Table 2).

On IVUS, in-stent volume of obstruction was $18.3 \pm 9.4 \%$, $32.8 \pm 19.1 \%$ and $9.8 \pm 2.4 \%$, and neointimal volume index was $1.58 \pm 0.75 \mathrm{~mm}^{3} / \mathrm{mm}, 2.93 \pm 1.76 \mathrm{~mm}^{3} / \mathrm{mm}$ and $0.80 \pm 0.16 \mathrm{~mm}^{3} / \mathrm{mm}$ in the SimvES, BMS, and EES groups, respectively (Table 3; Figure). There were no cases of acute or late incomplete apposition.

At 6-month clinical follow-up, all patients in the SimvES and EES groups were asymptomatic and there were no major adverse clinical events, such as cardiac or non-cardiac death, myocardial infarction, cerebrovascular accident or target vessel revascularization. One patient from the BMS group developed progressive chest pain on exertion and required early angiographic control at 4.5 months, which showed in-stent restenosis.

\section{Discussion}

Simvastatin is readily available and well absorbed when taken orally. The local drug concentration achieved by local delivery through a DES, however, cannot be achieved by oral intake without a high risk of systemic toxic effects. ${ }^{17,18}$
In this first-in-man study, there was neither stent thrombosis nor restenosis with the use of the SimvES. There were also no cardiac deaths or deaths due to any cause, and no myocardial infarctions during hospital stay or within 6 months after stent implantation.

In the SimvES group, QCA indicated a late loss of $1.05 \mathrm{~mm}$ at 6 months; this was similar to findings in the BMS group as well as to the historical results of BMS studies $(0.71-0.84 \mathrm{~mm}){ }^{19,20}$ This late loss, however, was higher than that found in the EES group and with most first-generation DES, such as sirolimus-eluting $(0.17 \mathrm{~mm})^{21}$ and paclitaxel-eluting stents $(0.36-0.39 \mathrm{~mm}),{ }^{19,22}$ and second-generation DES, such as EES $(0.10-0.12 \mathrm{~mm}),{ }^{20,23}$ and zotarolimus-eluting stents $(0.61 \mathrm{~mm}) .{ }^{24} \mathrm{In}$-stent diameter stenosis was $33.5 \%$, again closer to the BMS group as well as to the historical results from BMS $(37.2 \%)^{22}$ but higher than the EES group as well as with most DES, such as sirolimus-eluting stents $(10.4 \%),{ }^{21}$ paclitaxel-eluting stents $(13.5-17.4 \%),{ }^{19,22}$ EES $(5.9 \%)^{25}$ and zotarolimus-eluting stents $(22.4-27.9 \%) .{ }^{24,26,27}$

On IVUS, in-stent volume obstruction was found to be $18.3 \%$, which was significantly lower than that found in the BMS group or that reported in historical BMS studies (28.1-33.4\%). ${ }^{20,21,28}$ The SimvES volume obstruction, however, was significantly higher than that found in the EES group and that reported for sirolimus-eluting stents $(2.0-3.1 \%),{ }^{21,29}$ paclitaxel-eluting stents $(8.0-13.0 \%),{ }^{28}$ EES (3.5-8.0\%), ${ }^{20,30}$ and zotarolimus-eluting stents $(2.2-3.7 \%) .{ }^{31}$ Volume obstruction was also lower with the new novolimus-eluting stent $(6.0 \%) .^{32}$ The neointimal volume index of $1.58 \mathrm{~mm}^{3} / \mathrm{mm}$ was also significantly lower than that found in the BMS group, but significantly higher than that of the EES group, and again higher than the historical indices reported for EES $\left(0.2-0.4 \mathrm{~mm}^{3} / \mathrm{mm}\right),{ }^{30}$ zotarolimus-eluting stents $(0.2-$ 

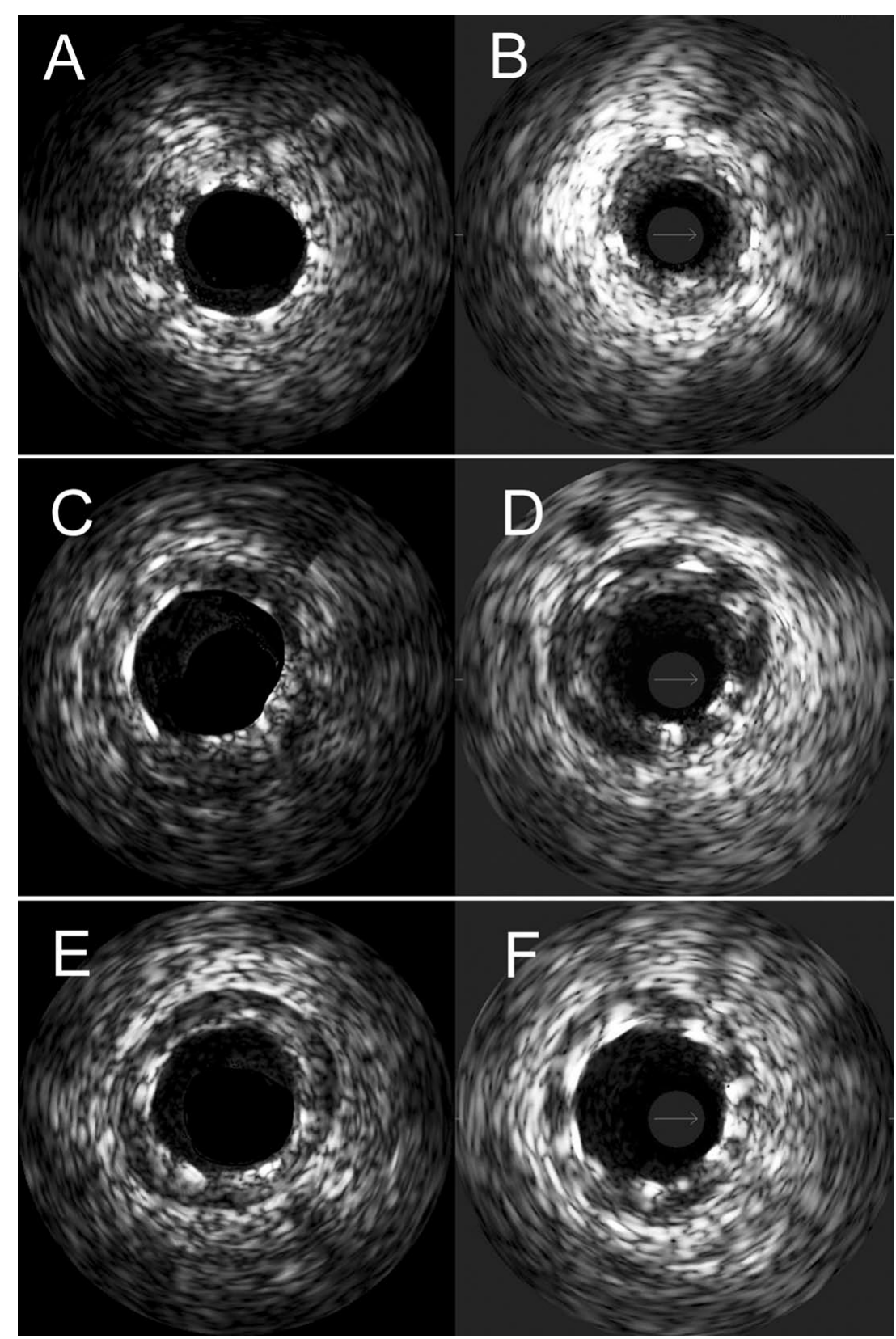

Figure. Intravascular ultrasound images. (A) Bare-metal stent at index procedure and (B) at follow-up; (C) simvastatin-eluting stent at index procedure and (D) at follow-up; (E) everolimus-eluting stent at index procedure and $(\mathbf{F})$ at follow-up $\left.0.3 \mathrm{~mm}^{3} / \mathrm{mm}\right)^{31}$ and novolimus-eluting stents $\left(0.42 \mathrm{~mm}^{3} / \mathrm{mm}\right){ }^{32}$ Therefore, the present study showed that the SimvES is associated with less neointimal proliferation than BMS, but more neointimal proliferation than all other DES.

The subjects did not significantly differ in terms of baseline clinical and procedural characteristics in the 3 treatment groups. Diabetes mellitus, which is a well-known predictor of restenosis, was present in approximately $30-35 \%$ of patients, as usually seems to occur in current practice. Non-ST elevation acute coronary syndrome was the most common clinical presentation (approximately $60 \%$ of patients) according to current practice, especially after the COURAGE trial; ${ }^{33}$ moreover, previous firstin-man studies have also included patients with acute coronary syndrome. ${ }^{19,34}$

The SimvES has shown no focal advantage as compared with the BMS, because both exhibited similar rates of in-stent late loss and diameter stenosis; the SimvES, however, provided better overall results due to the lower in-stent volume obstruction and neointimal volume index, which suggest an antiproliferative effect of simvastatin over smooth muscle cell proliferation that constitutes the basis of in-stent restenosis. ${ }^{35}$ Nevertheless, the higher-than-expected rates of in-stent late loss, diameter stenosis, in-stent volume obstruction and neointimal volume index after implantation of the SimvES in comparison to the EES or to all other DES suggest that simvastatin is not as potent as antiproliferative drugs from the -limus family or paclitaxel. Therefore, the overall performance of the SimvES appears to be intermediate, being closer to that of BMS than to that of any other DES currently available in clinical practice.

Experimental studies with drugs other than the -limus family or paclitaxel have been performed due to their potential drawback of delaying vascular healing, leading to an increased 
risk of late in-stent thrombosis and requiring prolonged dual antiplatelet therapy. One experimental in vitro and in vivo study with fludarabine, a nucleoside analog with anti-inflammatory and antiproliferative cellular effects, showed marked inhibition of smooth vascular cell proliferation in cell culture, as well as reduced neointimal formation after balloon angioplasty and reduced neointimal hyperplasia by $50 \%$ with the use of fludarabine-eluting stent compared to BMS in rabbits. ${ }^{36}$

Other experimental studies with angioplasty and/or stent deployment have shown that simvastatin reduces neointimal formation. An experimental study showed that simvastatin inhibits vascular smooth muscle cell proliferation in vitro and reduces neointimal formation in a dose-dependent manner in a rat model of vascular injury, either after balloon angioplasty or after stent deployment. ${ }^{6}$ That study also demonstrated that the effects of simvastatin on cell proliferation was independent of the cholesterol concentration and dependent on the inhibition of the mevalonate pathway. Another experimental study in mice showed that simvastatin reduces neointimal thickening, cellular proliferation and leukocyte accumulation after angioplasty. ${ }^{3}$ A cerivastatin-eluting stent was found to significantly reduce neointimal hyperplasia and to decrease early inflammatory response without inducing endothelial dysfunction in a porcine coronary model. ${ }^{7}$ Moreover, the SimvES under evaluation in the present trial promoted a significant reduction of neointimal hyperplasia and inflammatory cell infiltrates compared to BMS. ${ }^{10}$

Despite these promising results of simvastatin in pre-clinical studies, this first-in-man study did not support the satisfactory results reported in previous experimental studies in humans. Two possible explanations for the lower-than-expected neointimal inhibition are: (1) lower efficacy of simvastatin in humans than in animals due to pathophysiological differences; or (2) a higher therapeutic threshold in humans as compared to animals. Thus, increasing the drug load of SimvES in an attempt to achieve better angiographic and ultrasonographic results could be an important change to be evaluated before drug failure is considered.

\section{Study Limitations}

First, this first-in-man study enrolled a small number of patients, but the sample size was adequate to show statistically significant results. Second, the short-term results (6 months) may not predict subsequent findings, especially after discontinuation of dual antiplatelet therapy. Finally, the challenge of calculating the therapeutic drug load in humans on the basis of experimental studies alone, is noted.

\section{Conclusion}

The SimvES evaluated herein was not related to major adverse cardiac events, but it was associated with a higher level of neointimal proliferation than expected. This can be attributed either to inadequate drug load or to the inefficacy of simvastatin in properly controlling neointimal proliferation in humans. Therefore, further evaluation of a SimvES with a higher drug load should be considered before simvastatin is ruled out as a potential agent for prevention of in-stent restenosis.

\section{References}

1. Balk EM, Karas RH, Jordan HS, Kupelnick B, Chew P, Lau J. Effects of statins on vascular structure and function: A systematic review. Am J Med 2004; 117: 775-790.

2. Libby P, Okamoto Y, Rocha VZ, Folco E. Inflammation in atherosclerosis: Transition from theory to practice. Circ J 2010; 74: 213-220.

3. Chen Z, Fukutomi T, Zago AC, Ehlers R, Detmers PA, Wright SD, et al. Simvastatin reduces neointimal thickening in low-density lipoprotein receptor-deficient mice after experimental angioplasty without changing plasma lipids. Circulation 2002; 106: 20-23.

4. Zhou Q, Liao JK. Pleiotropic effects of statins: Basic research and clinical perspectives. Circ J 2010; 74: 818-826.

5. Indolfi C, Curcio A, Chiariello M. Simvastatin reduces neointimal thickening after experimental angioplasty. Circulation 2003; 107: e25.

6. Indolfi C, Cioppa A, Stabile E, Di Lorenzo E, Esposito G, Pisani A, et al. Effects of hydroxymethylglutaryl coenzyme A reductase inhibitor simvastatin on smooth muscle cell proliferation in vitro and neointimal formation in vivo after vascular injury. J Am Coll Cardiol 2000; 35: $214-221$.

7. Miyauchi K, Kasai T, Yokayama T, Aihara K, Kurata T, Kajimoto K, et al. Effectiveness of statin-eluting stent on early inflammatory response and neointimal thickness in a porcine coronary model. Circ J 2008; 72: 832-838.

8. Walter DH, Schachinger V, Elsner M, Mach S, Auch-Schwelk W, Zeiher AM. Effect of statin therapy on restenosis after coronary stent implantation. Am J Cardiol 2000; 85: 962-968.

9. Yokoyama T, Miyauchi K, Kurata T, Satoh H, Daida H. Inhibitory efficacy of pitavastatin on the early inflammatory response and neointimal thickening in a porcine coronary after stenting. Atherosclerosis 2004; 174: 253-259.

10. Casani L, Juan O, Serra A, Duocastella L, Molina M, Garcia-Rafanell $\mathrm{J}$, et al. A new DES with anti-inflammatory and antiproliferative activity reduces in-stent restenosis. Eur Heart J 2009; 30 (Abstract Supplement): 532 .

11. Jaschke B, Michaelis C, Milz S, Vogeser M, Mund T, Hengst L, et al. Local statin therapy differentially interferes with smooth muscle and endothelial cell proliferation and reduces neointima on a drug-eluting stent platform. Cardiovasc Res 2005; 68: 483-492.

12. Kaneko H, Kijima M. Role of bare-metal stents for left main coronary artery disease in the era of drug-eluting stents. Circ J 2011; 75: 1243 1249.

13. Kadota K, Mitsudo K. Percutaneous coronary intervention with drugeluting stent for unprotected left main trunk disease: Safety and efficacy compared with bare metal stent. Circ J 2011; 75: 1250-1254.

14. Hoye A, van der Giessen WJ. New approaches to ostial and bifurcation lesions. J Interv Cardiol 2004; 6: 397-403.

15. Task Force on Myocardial Revascularization of the European Society of Cardiology (ESC) and the European Association for Cardio-Thoracic Surgery (EACTS); European Association for Percutaneous Cardiovascular Interventions (EAPCI), Wijns W, Kolh P, Danchin N, Di Mario C, Falk V, Folliguet T, et al. Guidelines on myocardial revascularization. Eur Heart J 2010; 31: 2501 - 2555 .

16. Cutlip DE, Windecker S, Mehran R, Boam A, Cohen DJ, van Es GA, et al. Clinical end points in coronary stent trials: A case for standardized definitions. Circulation 2007; 115: 2344-2351.

17. Brara PS, Moussavian M, Grise MA, Reilly JP, Fernandez M, Schatz $\mathrm{RA}$, et al. Pilot trial of oral rapamycin for recalcitrant restenosis. Circulation 2003; 107: 1722-1724

18. Kothwala D, Raval A, Choubey A, Engineer C, Kotadia H. Paclitaxel drug delivery from cardiovascular stent. Trends Biomater Artif Organs 2006; 19: 88-92.

19. Grube E, Silber S, Hauptmann KE, Mueller R, Buellesfeld L, Gerckens $\mathrm{U}$, et al. TAXUS I: Six- and twelve-month results from a randomized, double-blind trial on a slow-release paclitaxel-eluting stent for de novo coronary lesions. Circulation 2003; 107: 38-42.

20. Serruys PW, Ong AT, Piek JJ, Neumann FJ, van der Giessen WJ, Wiemer M, et al. A randomized comparison of a durable polymer everolimus-eluting stent with a bare metal coronary stent: The SPIRIT first trial. EuroIntervention 2005; 1: 58-65.

21. Moses JW, Leon MB, Popma JJ, Fitzgerald PJ, Holmes DR, O'Shaughnessy C, et al. Sirolimus-eluting stents versus standard stents in patients with stenosis in a native coronary artery. $N$ Engl J Med 2003; 349: 1315-1323.

22. Stone GW, Ellis SG, Cox DA, Hermiller J, O'Shaughnessy C, Mann $\mathrm{JT}$, et al. A polymer-based, paclitaxel-eluting stent in patients with coronary artery disease. N Engl J Med 2004; 350: 221 -231.

23. Serruys PW, Ruygrok P, Neuzner J, Piek JJ, Seth A, Schofer JJ, et al. A randomised comparison of an everolimus-eluting coronary stent with a paclitaxel-eluting coronary stent: The SPIRIT II trial. EuroIntervention 2006; 2: 286-294.

24. Meredith IT, Ormiston J, Whitbourn R, Kay IP, Muller D, Bonan R, et al. First-in-human study of the Endeavor ABT-578-eluting phosphorylcholine-encapsulated stent system in de novo native coronary artery lesions: Endeavor I Trial. EuroIntervention 2005; 1: 157-164.

25. Stone GW, Midei M, Newman W, Sanz M, Hermiller JB, Williams $\mathrm{J}$, et al. Comparison of an everolimus-eluting stent and a paclitaxeleluting stent in patients with coronary artery disease: A randomized 
trial. JAMA 2008; 299: 1903-1913.

26. Fajadet J, Wijns W, Laarman GJ, Kuck KH, Ormiston J, Munzel T, et al. Randomized, double-blind, multicenter study of the Endeavor zotarolimus-eluting phosphorylcholine-encapsulated stent for treatment of native coronary artery lesions: Clinical and angiographic results of the ENDEAVOR II trial. Circulation 2006; 114: 798-806.

27. Kandzari DE, Leon MB, Popma JJ, Fitzgerald PJ, O'Shaughnessy C, Ball MW, et al. Comparison of zotarolimus-eluting and sirolimuseluting stents in patients with native coronary artery disease: A randomized controlled trial. J Am Coll Cardiol 2006; 48: 2440-2447.

28. Waseda K, Miyazawa A, Ako J, Hasegawa T, Tsujino I, Sakurai R, et al. Intravascular ultrasound results from the ENDEAVOR IV trial: Randomized comparison between zotarolimus- and paclitaxel-eluting stents in patients with coronary artery disease. JACC Cardiovasc Interv 2009; 2: 779-784

29. Sousa JE, Costa MA, Abizaid AC, Rensing BJ, Abizaid AS, Tanajura LF, et al. Sustained suppression of neointimal proliferation by sirolimus-eluting stents: One-year angiographic and intravascular ultrasound follow-up. Circulation 2001; 104: 2007-2011.

30. Shimohama T, Ako J, Yamasaki M, Otake H, Tsujino I, Hasegawa $\mathrm{T}$, et al. SPIRIT III Japan versus SPIRIT III USA: A comparative intravascular ultrasound analysis of the everolimus-eluting stent. Am J Cardiol 2010; 106: 13-17.

31. Waseda K, Ako J, Yamasaki M, Koizumi T, Ormiston J, Worthley
SG, et al. Short- and mid-term intravascular ultrasound analysis of the new zotarolimus-eluting stent with durable polymer: Results from the RESOLUTE trial. Circ J 2010; 74: 2097-2102.

32. Costa JR Jr, Abizaid A, Feres F, Costa R, Seixas AC, Maia F, et al. EXCELLA first-in-man (FIM) study: Safety and efficacy of novolimus-eluting stent in de novo coronary lesions. EuroIntervention 2008; 4: $53-58$.

33. Boden WE, O'Rourke RA, Teo KK, Hartigan PM, Maron DJ, Kostuk WJ, et al; COURAGE Trial Research Group. Optimal medical therapy with or without PCI for stable coronary disease: The COURAGE Trial. N Engl J Med 2007; 356: 1503-1516.

34. Sousa JE, Costa MA, Abizaid A, Abizaid AS, Feres F, Pinto IM, et al. Lack of neointimal proliferation after implantation of sirolimuscoated stents in human coronary arteries: A quantitative coronary angiography and three-dimensional intravascular ultrasound study. Circulation 2001; 103: $192-195$.

35. Curcio A, Torella S, Indolfi C. Mechanisms of smooth muscle cell proliferation and endothelial regeneration after vascular injury and stenting. Circ J 2011; 75: 1287-1296.

36. Torella D, Curcio A, Gasparri C, Galuppo V, De Serio D, Surace FC, et al. Fludarabine prevents smooth muscle proliferation in vitro and neointimal hyperplasia in vivo through specific inhibition of STAT-1 activation. Am J Physiol Heart Circ Physiol 2007; 292: H2935H2943. 